Check for updates

London

Cite this as: BMJ 2022;376:0111 http://dx.doi.org/10.1136/bmj.o111 Published: 14 January 2022

\title{
Covid-19: Warning over transmission risk as self-isolation is cut to five days in England
}

Susan Mayor

Organisations representing health professionals have cautioned over the need to minimise the risk of transmitting SARS-CoV-2, after the self isolation period in England following infection was cut from seven to five days.

From 17 January people in England can stop isolating at the start of the sixth day after first testing positive for covid-19, provided that they have two negative lateral flow tests on days 5 and 6 and do not have a raised temperature. People who test positive must continue to self-isolate until they have had two consecutive negative tests taken on separate days.

The health and social care secretary, Sajid Javid, said the change had been made "to maximise activity in the economy and education ... but also minimisethe risk of infectious people leaving isolation."

Explaining the reasoning, he said, "UK Health Security Agency data show that around two thirds of positive cases are no longer infectious by the end of day 5 , and we want to use the testing capacity that we've built up to help these people leave isolation safely."

A Department of Health and Social Care statement said that modelling from the agency showed that around $7 \%$ of people remained infectious if they left isolation on day 6 after two consecutive negative rapid lateral flow tests. ${ }^{1}$

However, organisations representing health professionals are concerned about the risk of viral transmission to patients and colleagues because many still do not have access to adequate personal protective equipment.

Penelope Toff, chair of the BMA's public health medicine committee, told The BMJ, "All sectors, and in particularly the health service, are experiencing disruption from widespread absences due to the rapid spread of omicron, but healthcare workers do not want to risk infecting colleagues and patients, many of whom are clinically vulnerable. So they can only return to work safely after a shorter period of isolation and two negative lateral flow tests if they have access to high grade masks, and many are finding that this is still not the case."

She cautioned, "For other key workers and members of the public, there must be a clear understanding that there is still a risk they can infect others, so they should be cautioned to take particular care to wear masks, keep their distance, and ensure there is adequate ventilation indoors."

The Royal College of Nursing has argued that the reduction in self-isolation should not apply to health and care workers. Pat Cullen, its general secretary and chief executive, said, "Current and growing workforce pressures must not drive a reduction in isolation requirements in an unsafe way."

Scientists warned that shortening the isolation period after infection with the omicron variant did not follow the science, particularly as preliminary data from the National Institute of Infectious Diseases, which carries out disease surveillance in Japan, found that the amount of viral RNA was highest 3-6 days after diagnosis or symptom onset. ${ }^{2}$ This appears to be two or three days later than with other variants.

Lawrence Young, professor of molecular oncology at Warwick Medical School, said, "Reducing the self-isolation period to five days runs the risk of highly infectious people returning to work or school, particularly if people don't use lateral flow tests as advised on days 5 and 6."

He suggested that the shorter isolation period be introduced only with strict enforcement of lateral flow testing, adding, "This is not helped by current problems with the availability of lateral flow tests and with concerns about people reporting the results from these tests.”

1 Department of Health and Social Care. Self-isolation for those with covid-19 can end after 5 full days following 2 negative LFD tests. 13 Jan 2022 https://www.gov.uk/government/news/self-isolation-for-those-with-covid19-can-end-after-five-full-days-following-two-negative-lfd-tests

2 Torjesen I. Covid-19: Peak of viral shedding is later with omicron variant, Japanese data suggest. BMJ 2022;376:089doi: 10.1136/bmj.089.

This article is made freely available for personal use in accordance with BMJ's website terms and conditions for the duration of the covid-19 pandemic or until otherwise determined by BMJ. You may download and print the article for any lawful, non-commercial purpose (including text and data mining) provided that all copyright notices and trade marks are retained. 